\title{
The Role of E-Commerce in Improving Customer Satisfaction
}

\author{
H. Bhaskar Shetty ${ }^{1}$, Ms. Sowmya $L^{2}$ \\ ${ }^{1}$ Assistant Professor, ${ }^{2}$ Student \\ 1,2SRJ PU College for Women, Department of Commerce, Bangalore, Karnataka, India
}

\begin{abstract}
How to cite this paper: $\mathrm{H}$. Bhaskar Shetty | Ms. Sowmya L "The Role of ECommerce in Improving Customer Satisfaction" Published in International Journal of Trend in Scientific Research and Development (ijtsrd), ISSN: 24566470, Volume-3 | Issue-4, June 2019, pp.802-807, URL: https://www.ijtsrd.c om/papers/ijtsrd23 904.pdf

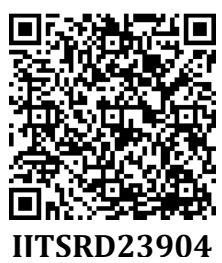

Copyright (c) 2019 by author(s) and International Journal of Trend in Scientific Research and Development Journal. This is an Open Access article distributed under the terms of the Creative Commons

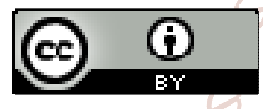
Attribution License (CC BY 4.0) (http://creativecommons.org/licenses/ by $/ 4.0$ )

Better internet connectivity, better technology, greater access to smart phones and other mobile devices are the drivers for this growth. Various initiatives by government of India like Digital India, Make in India, Startup-India and Skill India provide greater inputs to the e-commerce industry in the country. The e-commerce online shopping is not only improving in terms of buyers and retail transaction, but also improving in terms of its stretch out and coverage. The introduction of e-commerce has seen a sensational clash on the traditional ways of doing business. It is a new trend in the world of commerce or business. E-commerce will become an essential element in every business and everywhere in our life shortly. It built a situation in the economy where all the business must get them in ecommerce either the business is big or small, or else they have to lose the market or quit. The e-commerce gradually changing the way you shop, learn, interact and transact business. In the emerging global economy e-commerce and e-business have progressively become essential aspect of business strategy and also in economic development.

\footnotetext{
REASONS WHY CUSTOMER SATISFACTION IS IMPORTANT

$>$ Preserving satisfied customer is cheaper than acquiring new ones.

$>$ Customer satisfaction is more significant than price.

$>$ Customer satisfaction keeps your brand front of the competitors.

$>$ Customer satisfaction aid for customer retention.
}

$>$ Customer satisfaction elevates customer loyalty.

$\rightarrow$ Customer satisfaction reduces advertisement cost as there is word of mouth publicity.

$>$ Customer satisfaction is a factor that helps you stand out of the competition.

\section{LITERATURE REVIEW}

Meaning of e-commerce and customer satisfaction

Ecommerce is the combination of communication and information sharing technology which is facilitated by an electronic medium to do business activity and achieve business objective.

Customer satisfaction means the degree to which a customer is happy with their trade experience with the company. It measures how well a firm is able to meet their customer's expectations. Customer satisfaction is a key factor in marketing because a firm cannot retain its customers unless having highly satisfied customers.

Elizabeth Goldsmith and Sue L.T. McGregor (2000) analyzed the impact of e-commerce on consumers, public policy, business and education. A discussion was on public policy initiatives, research questions and ideas for future research are given. Patric Barwise (2001) reported that probability 99 $\%$ of e-commerce today is done using PCs either desktops or Laptops. For B2B e-commerce this is not easily possible to change for $\mathrm{B} 2 \mathrm{C}$ e-commerce however, things will be more complex, there will be wider range of relevant media including interactive digital TV and a range of mobile and 
wireless service there will be huge difference between different consumer's ownership tools and access technology. Some will have broadband access and others may not have digital communication at all. Jackie Gilbert Bette Ann Stead (2001) reviewed the incredible growth of electronic commerce (e-commerce) and presented ethical issues that have emerged. Security concerns, spamming, websites that do not carry an "advertising" label, cyber squatters, online marketing to children, conflicts of interest, manufacturers competing with intermediaries online and "dinosaurs" were considered. Diana Oblinger (2001) reported that one is that education and continuous learning have become so vital in all societies that the demands for distance and open learning will increase. As the availability of the Internet expands as computing devices become cheaper and an energy requirements and form factors shrink, learning will become more popular. Prithviraj Dasgupta and Kasturi Sengupta (2002) reported that the recent growth of Internet Infrastructure and Introduction of economic reforms in the Insurance sector have opened up the monopolistic Indian Insurance market to competition from foreign alliances. Although the focus of e-commerce has been predominantly on business to consumer (B2C) applications the emphasis is now shifting towards business to business (B2B) applications. The Insurance Industry gives an appropriate model that combines both B2C and B2B applications.

James Christopher (2004) examined all the best elements of ecommerce do not guarantee consumers will visit or remain loyal. But looking at what they want and their satisfaction levels of other well established e-tailors such as Amazon and eBay who have already invested significant resources to understand what consumer's needs, wants and desires. Possibly it would be helpful to remove these established pure players since they have been and continue to be highly successful as retain high marks for customer satisfaction.

\section{OBJECTIVES OF THE STUDY}

$>$ To study the awareness of E-Commerce in customers.

$>$ To analyze the attitude of customers towards ECommerce.

$>$ To find out the how well E-Commerce satisfying customers.

\section{METHODOLOGY \\ DATA COLLECTION}

The study was conducted using random sampling method. The study was based on both primary data and secondary data. The Primary Data had been collected through structured questionnaire. The Secondary data had been collected from journals, books and magazines for the study. The size of the sample have been approximated to respondents who are customers presently purchasing products using E-Commerce. In this study Random sampling method is used. Sampling technique is simple random sample method. The sampling size refers to the number of elements to be chosen from the population to conduct sample. For this study sample size was 80 .

\section{DATA ANALYSIS}

TABLE-1 GENDER - WISE CLASSIFICATION OF RESPONDENTS

\begin{tabular}{|l|l|l|}
\hline Gender & Respondents & Percentage \\
\hline Male & 59 & $73.75 \%$ \\
\hline Female & 21 & $26.25 \%$ \\
\hline
\end{tabular}

(Source: Primary data)

\section{1: INTERPRETATION}

In the study, more than half of the respondents were male and remaining are female respondents. In the whole sample respondent population $73.75 \%$ were male respondents and remaining $26.25 \%$ were female respondents.

TABLE-2 AGE - WISE CLASSIFICATION OF RESPONDENTS

\begin{tabular}{|c|c|c|}
\hline Age & Respondents & Percentage \\
\hline 18-29 years & 44 & $55 \%$ \\
\hline 30-39 years & 24 & $30 \%$ \\
\hline 40-49 years & 9 & $11.25 \%$ \\
\hline Above 50 years & 3 & $3.75 \%$ \\
\hline
\end{tabular}

(Source: Primary data)

\section{2: INTERPRETATION}

The above figure represents that the classification of respondents based on their age. There were 55\% respondents whose age is between 18-29 years, 30\% respondents whose age between 30-39 years, $11.25 \%$ respondents whose age between $40-49$ years and 3.75\% respondents above 50 years.

\section{TABLE-3 EDUCATIONAL QUALIFICATION OF} RESPONDENTS

\begin{tabular}{|c|c|c|}
\hline Education qualification & Respondents & Percentage \\
\hline SSLC & 11 & $13.75 \%$ \\
\hline PUC & 18 & $22.5 \%$ \\
\hline Graduation & 42 & $52.5 \%$ \\
\hline Post Graduation & 9 & $11.25 \%$ \\
\hline
\end{tabular}

(Source: Primary data)

\section{3: INTERPRETATION}

The chart represents that $53 \%$ of respondents are graduates, $22 \%$ of respondents are PUC, $14 \%$ of respondents are SSLC and rest $11 \%$ of respondents are post graduates. Majority of the respondents are graduates.

\section{TABLE-4 OCCUPATION OF RESPONDENTS}

\begin{tabular}{|c|c|c|}
\hline Occupation & Respondents & Percentage \\
\hline Student & 41 & $51.25 \%$ \\
\hline Business & 20 & $25 \%$ \\
\hline House wife & 13 & $16.25 \%$ \\
\hline Employee & 6 & $7.5 \%$ \\
\hline
\end{tabular}

(Source: Primary data)

\section{4: INTERPRETATION}

The figure shows that $51 \%$ of respondents are students, $25 \%$ of respondents are business people, $16 \%$ of respondents are house wives and only $8 \%$ of respondents are employees. It means the using populations of e-commerce are students.

\section{TABLE-5 MARITAL STATUS OF RESPONDENTS}

\begin{tabular}{|c|c|c|}
\hline Marital status & Respondents & Percentage \\
\hline Married & 22 & $27.5 \%$ \\
\hline Single & 58 & $72.5 \%$ \\
\hline
\end{tabular}

(Source: Primary data)

\section{5: INTERPRETATION}

The above chart shows that $72.5 \%$ of the respondent population are single and rest $27.5 \%$ of the respondent population are married. It represents that there is an influence of marital status in the usage of e-commerce. 
International Journal of Trend in Scientific Research and Development (IJTSRD) @ www.ijtsrd.com eISSN: 2456-6470

TABLE-6 E-COMMERCE AWARENESS

\begin{tabular}{|c|c|c|}
\hline $\begin{array}{c}\text { Since when you are } \\
\text { aware of e-commerce }\end{array}$ & Respondents & Percentage \\
\hline 1-5 years & 74 & $92.5 \%$ \\
\hline 5-10 years & 6 & $7.5 \%$ \\
\hline >10 years & 0 & $0 \%$ \\
\hline I don't know & 0 & $0 \%$ \\
\hline
\end{tabular}

(Source: Primary data)

\section{6: INTERPRETATION}

The above chart represents that $92.5 \%$ of respondents' population are aware of e-commerce since 1-5 years. Among the whole sample population, $7.5 \%$ of them were aware of ecommerce since 10 years. There were no respondents who were not aware of e-commerce.

TABLE-7 TIME PERIOD OF USAGE OF E-COMMERCE

\begin{tabular}{|c|c|c|}
\hline $\begin{array}{c}\text { Since how many } \\
\text { years are you using } \\
\text { e-commerce? }\end{array}$ & Respondents & Percentage \\
\hline 1-5 years & 42 & $52.5 \%$ \\
\hline 5-10 years & 4 & $5 \%$ \\
\hline >10 years & 0 & $0 \%$ \\
\hline Not yet used & 34 & $42.5 \%$ \\
\hline
\end{tabular}

(Source: Primary data)

\section{7: INTERPRETATION}

The above chart represents that $52.5 \%$ of respondents are using e- commerce since 5 years. There are $5 \%$ of respondents who are using since 10 years and $42.5 \%$ of the respondents have not yet used e-commerce till today.

TABLE-8 PURPOSE OF USING E-COMMERCE

\begin{tabular}{|c|c|c|}
\hline $\begin{array}{c}\text { Purpose for use e- } \\
\text { commerce is }\end{array}$ & Respondents & Percentage \\
\hline Personal use (BUYING) & 72 & $90 \%$ \\
\hline Business use (SELLING) & 8 & $10 \%$ \\
\hline $\begin{array}{c}\text { Both personal and } \\
\text { business use }\end{array}$ & 0 & $0 \%$ \\
\hline
\end{tabular}

(Source: Primary data)

\section{8: INTERPRETATION}

The chart shows that $90 \%$ of the respondent population is making use of online commerce or e-commerce for personal use. Rest $10 \%$ of population is making use of e-commerce for business purpose. There are no respondents who are making use of online commerce both for personal and business purpose.

TABLE-9 BENEFITS OF E-COMMERCE TO CONSUMERS

\begin{tabular}{|c|c|c|}
\hline $\begin{array}{c}\text { How do you think e- } \\
\text { commerce is benefited } \\
\text { to consumers }\end{array}$ & Respondents & Percentage \\
\hline $24 / 7$ accessibility & 0 & $0 \%$ \\
\hline $\begin{array}{c}\text { Broadens consumers } \\
\text { choice }\end{array}$ & 0 & $0 \%$ \\
\hline Comparative price & 0 & $0 \%$ \\
\hline All the above & 80 & $100 \%$ \\
\hline
\end{tabular}

(Source: Primary data)

\section{9: INTERPRETATION}

The total respondent population (100\%) has chosen all the above options. It means that consumers are benefited with 24/7 accessibility, broadens consumers choice and comparative price.
TABLE-10 BENEFITS OF E-COMMERCE TO BUSINESS

\begin{tabular}{|c|c|c|}
\hline $\begin{array}{c}\text { How do you think e- } \\
\text { commerce helps the } \\
\text { business }\end{array}$ & Respondents & Percentage \\
\hline Smoothens business & 16 & $20 \%$ \\
\hline $\begin{array}{c}\text { Less startup, } \\
\text { transaction and } \\
\text { inventory cost }\end{array}$ & 8 & $10 \%$ \\
\hline Global reach & 44 & $55 \%$ \\
\hline All the above & 12 & $15 \%$ \\
\hline
\end{tabular}

(Source: Primary data)

\section{0: INTERPRETATION}

The chart shows that $55 \%$ of sample population's opinion is global reach which is a major benefit by e-commerce to the business. $20 \%$ of respondents say that e-commerce benefits the business by smoothening the business. $10 \%$ of respondents say it reduces the cost to the business. Remaining $15 \%$ of respondents say all of those options are the benefits of e-commerce to the business.

\section{TABLE-11 THE EXTENT TO WHICH E-COMMERE MEETS NEEDS OF CONSUMERS}

\begin{tabular}{|c|c|c|}
\hline $\begin{array}{c}\text { do products in e- } \\
\text { commerce meet need }\end{array}$ & Respondents & Percentage \\
\hline Badly & 6 & $7.5 \%$ \\
\hline Fine & 10 & $12.5 \%$ \\
\hline Well & 24 & $30 \%$ \\
\hline Very well & 40 & $50 \%$ \\
\hline
\end{tabular}

(Source: Primary data)

\section{1: INTERPRETATION}

The above chart shows that $50 \%$ of population says that products meet their needs very well. $30 \%$ of the respondents say that products meet their needs well. $12.5 \%$ of respondents say that products are fine in meeting their needs and $7.5 \%$ of the population says that products meet their needs badly.

\section{TABLE-12 CLEAR PRE-INFORMATION ABOUT GOODS AND SERVICES}

\begin{tabular}{|c|c|c|}
\hline $\begin{array}{c}\text { Adequate and clear } \\
\text { product information }\end{array}$ & Respondents & Percentage \\
\hline Strongly disagree & 0 & $0 \%$ \\
\hline Disagree & 12 & $15 \%$ \\
\hline Neutral & 6 & $7.5 \%$ \\
\hline Agree & 42 & $52.5 \%$ \\
\hline Strongly agree & 20 & $25 \%$ \\
\hline
\end{tabular}

(Source: Primary data)

\section{2: INTERPRETATION}

The above chart shows that $52.5 \%$ of respondents agree, $25 \%$ of respondents strongly agree, $7.5 \%$ of them are neutral and $15 \%$ of respondents disagree with the statements that pre-information is adequate.

\section{TABLE-13 E-COMMERCE MADE IT EASY TO HANDLE PURCHASES}

The e-commerce made easy to handle my issues. Respondents Percentage

\begin{tabular}{|c|c|c|}
\hline Strongly disagree & 0 & $0 \%$ \\
\hline Disagree & 2 & $2.5 \%$ \\
\hline Neutral & 8 & $10 \%$ \\
\hline Agree & 58 & $72.5 \%$ \\
\hline Strongly agree & 12 & $15 \%$ \\
\hline
\end{tabular}

(Source: Primary data) 
International Journal of Trend in Scientific Research and Development (IJTSRD) @ www.ijtsrd.com eISSN: 2456-6470

\section{3: INTERPRETATION}

The chart shows that $72.5 \%$ of the population agrees that $\mathrm{e}$ commerce made it easy to handle the purchase issues. $15 \%$ of the population strongly agrees, $10 \%$ of them are neutral and $2.5 \%$ of them disagree by saying that e-commerce made it easy to handle purchase issues.

TABLE-14 PRICE OF PRODUCTS ARE COMPETITIVE The price of product

or services on website Respondents Percentage is competitive

\begin{tabular}{|c|c|c|}
\hline Strongly disagree & 4 & $5 \%$ \\
\hline Disagree & 10 & $12.5 \%$ \\
\hline Neutral & 14 & $17.5 \%$ \\
\hline Agree & 40 & $50 \%$ \\
\hline Strongly agree & 12 & $15 \%$ \\
\hline
\end{tabular}

(Source: Primary data)

\section{4: INTERPRETATION}

The above chart shows that $50 \%$ respondents in the sample population agree that the prices of products are competitive in e-commerce. Among the population 15\% respondents strongly agree, $17.5 \%$ of them are neutral, $12.5 \%$ of them disagree and $5 \%$ of them strongly disagree that the prices of the product are competitive on e-commerce.

TABLE-15 PRODUCTS PRICES ARE CHEAP

\begin{tabular}{|c|c|c|}
\hline $\begin{array}{c}\text { Price of goods in } \\
\text { internet is cheaper. }\end{array}$ & Respondents & Percentage \\
\hline Strongly disagree & 20 & $25 \%$ \\
\hline Disagree & 6 & $7.5 \%$ \\
\hline Neutral & 8 & $10 \%$ Rer \\
\hline Agree & 46 & $57.5 \%$ \\
\hline Strongly agree & 0 & $0 \%$ \\
\hline
\end{tabular}

(Source: Primary data)

\section{5: INTERPRETATION}

The above graph shows that $57.5 \%$ respondents agree that product prices are cheaper. $25 \%$ respondents strongly disagree, $10 \%$ respondents are neutral, $7.5 \%$ of the respondents disagree that the price of products are cheaper.

\section{TABLE-16 BILLING AND SHIPPING INFORMATION ARE} SIMPLE

\begin{tabular}{|c|c|c|}
\hline $\begin{array}{c}\text { Billing and shipping } \\
\text { information is clear }\end{array}$ & Respondents & Percentage \\
\hline Strongly disagree & 0 & $0 \%$ \\
\hline Disagree & 16 & $20 \%$ \\
\hline Neutral & 32 & $40 \%$ \\
\hline Agree & 20 & $25 \%$ \\
\hline Strongly agree & 12 & $15 \%$ \\
\hline
\end{tabular}

(Source: Primary data)

\section{6: INTERPRETATION}

The chart shows that $25 \%$ of the population agrees that billing and shipping information are simple to understand. $15 \%$ respondents of the population strongly agree, $40 \%$ of them are neutral and $20 \%$ of them disagree for the question billing and shipping information are clear and easy to
TABLE-17 PRODUCT PERFORMANCE AS EXPECTED

\begin{tabular}{|c|c|c|}
\hline $\begin{array}{c}\text { Product performed } \\
\text { as I expected }\end{array}$ & Respondents & Percentage \\
\hline Strongly disagree & 16 & $20 \%$ \\
\hline Disagree & 24 & $30 \%$ \\
\hline Neutral & 24 & $30 \%$ \\
\hline Agree & 16 & $20 \%$ \\
\hline Strongly agree & 0 & $0 \%$ \\
\hline
\end{tabular}

\section{7: INTERPRETATION}

The above chart says that $30 \%$ respondents of the population have shown disagree and neutral response towards the question whether the products performed as they expected. $20 \%$ of respondents said that they agree and remaining $20 \%$ of them say that they strongly disagree for the statement products performed as they expected.

TABLE-18 SHOPPING IN E-COMMERCE IS TIME SAVING
\begin{tabular}{|c|c|c|}
\hline $\begin{array}{c}\text { Shopping in e-commerce } \\
\text { is time saving }\end{array}$ & Respondents & Percentage \\
\hline Strongly disagree & 0 & $0 \%$ \\
\hline Disagree & 0 & $0 \%$ \\
\hline Neutral & 4 & $5 \%$ \\
\hline Agree & 64 & $80 \%$ \\
\hline Strongly agree & 12 & $15 \%$ \\
\hline
\end{tabular}

(Stifi? (Source: Primary data)

\section{8: INTERPRETATION}

The above chart shows that $80 \%$ respondents of the sample population agree that e-commerce is time saving. $15 \%$ of the respondents strongly agreed and 5\% of them showed neutral response for the statement that e-commerce is time saving.

\section{TABLE-19 HOW RESPONSIVE IS E-COMMERCE TO CUSTOMER QUESTIONS}

\begin{tabular}{|c|c|c|}
\hline $\begin{array}{c}\text { How responsive is e- } \\
\text { commerce to customers }\end{array}$ & Respondents & Percentage \\
\hline Irresponsive & 10 & $12.5 \%$ \\
\hline Usually responsive & 56 & $70 \%$ \\
\hline Very responsive & 14 & $17.5 \%$ \\
\hline
\end{tabular}

(Source: Primary data)

\section{9: INTERPRETATION}

The above chart shows that $70 \%$ of them say that ecommerce is usually responsive. $17.5 \%$ of them say that they are very responsive and remaining $12.5 \%$ of them say that the e-commerce is irresponsive for the queries asked by the customers or consumers.

TABLE-20 AFTER SALES SERVICE OF E-COMMERCE

\begin{tabular}{|c|c|c|}
\hline $\begin{array}{c}\text { After sales service } \\
\text { of e-commerce }\end{array}$ & Respondents & Percentage \\
\hline Very bad & 0 & $0 \%$ \\
\hline Poor & 8 & $10 \%$ \\
\hline Fair & 66 & $82.5 \%$ \\
\hline Good & 6 & $7.5 \%$ \\
\hline Excellent & 0 & $0 \%$ \\
\hline
\end{tabular}

(Source: Primary data)

\section{0: INTERPRETATION}

The above graph shows that $82.5 \%$ respondents say that after sales service is fair. $10 \%$ respondents of the sample population say poor after sales service. $7.5 \%$ respondents say that after sales service is good in online or e-commerce. 
International Journal of Trend in Scientific Research and Development (IJTSRD) @ www.ijtsrd.com eISSN: 2456-6470

\section{TABLE-21 EASY TO CANCEL ORDER OR RETURN GOODS PURCHASED}

\begin{tabular}{|c|c|c|}
\hline $\begin{array}{c}\text { Easy to cancel order } \\
\text { or return goods } \\
\text { purchased }\end{array}$ & Respondents & Percentage \\
\hline Strongly disagree & 0 & $0 \%$ \\
\hline Disagree & 18 & $22.5 \%$ \\
\hline Neutral & 24 & $30 \%$ \\
\hline Agree & 34 & $42.5 \%$ \\
\hline Strongly agree & 4 & $5 \%$ \\
\hline
\end{tabular}

(Source: Primary data)

\section{1: INTERPRETATION}

The above graph shows $42.5 \%$ respondents are agreeing that it is easy to cancel order or return goods purchased through online. $30 \%$ respondents are neutral, $22.5 \%$ respondents disagree and rest 5\% respondents strongly agree that it is easy to cancel order and return the goods purchased.

TABLE-22 E-COMMERCE ELEMINATES MIDDLEMEN

\begin{tabular}{|c|c|c|}
\hline $\begin{array}{c}\text { E-commerce } \\
\text { eliminates middlemen }\end{array}$ & Respondents & Percentage \\
\hline Strongly disagree & 0 & $0 \%$ \\
\hline Disagree & 12 & $15 \%$ \\
\hline Neutral & 58 & $72.5 \%$ \\
\hline Agree & 10 & $12.5 \%$ \\
\hline Strongly agree & 0 & $0 \%$ \\
\hline
\end{tabular}

(Source: Primary data)

\section{2: INTERPRETATION}

The above graph shows that $72.5 \%$ of the respondents (58 respondents) gave neutral response, $15 \%$ respondents disagree and $12.5 \%$ respondents agree that e-commerce eliminates middlemen.

TABLE-23 FREQUENCY OF PURCHASE ANNUALLY

\begin{tabular}{|c|c|c|}
\hline $\begin{array}{c}\text { Frequently of } \\
\text { purchase }\end{array}$ & Respondents & Percentage \\
\hline Purchase once annually & 8 & $10 \%$ \\
\hline $2-5$ purchase & 40 & $50 \%$ \\
\hline $6-10$ purchase & 20 & $25 \%$ \\
\hline 11 and above purchases & 12 & $15 \%$ \\
\hline
\end{tabular}

(Source: Primary data)

\section{3: INTERPRETATION}

The above graph shows $50 \%$ respondents of the population usually purchase 2-5 times annually. 25\% respondents purchase 6-10 times annually. 15\% of them purchase 11 and above times annually and $10 \%$ of them purchase once annually.

\section{TABLE-24 LIKELY TO BUY AGAIN}

\begin{tabular}{|c|c|c|}
\hline How likely to buy again & Respondents & Percentage \\
\hline Not likely at all & 0 & $0 \%$ \\
\hline Not likely & 36 & $45 \%$ \\
\hline Neutral & 0 & $0 \%$ \\
\hline Likely & 44 & $55 \%$ \\
\hline Very likely & 0 & $0 \%$ \\
\hline
\end{tabular}

(Source: Primary data)

\section{4: INTERPRETATION}

The above chart shows that 55\% respondents are likely to buy again through online or e-commerce. Remaining $45 \%$ respondents have said that they are not likely to buy again through e-commerce.
TABLE-25 HOW GOOD E-COMMERCE IS OVER TRADITIONAL COMMERCE

\begin{tabular}{|c|c|c|}
\hline $\begin{array}{c}\text { How good is e- } \\
\text { commerce than } \\
\text { traditional commerce }\end{array}$ & Respondents & Percentage \\
\hline Very bad & 0 & $0 \%$ \\
\hline Poor & 10 & $12.5 \%$ \\
\hline Fair & 24 & $30 \%$ \\
\hline Good & 40 & $50 \%$ \\
\hline Excellent & 6 & $7.5 \%$ \\
\hline
\end{tabular}

(Source: Primary data)

\section{5: INTERPRETATION}

The above chart represents that $50 \%$ respondents say that ecommerce is good over traditional commerce. 30\% respondents are saying that e-commerce is fair enough than traditional commerce. Among remaining 7.5\% respondents excellent and $12.5 \%$ respondents say poor about how good e-commerce is over traditional commerce.

\section{TABLE-26 LIKELY TO RECOMMEND}

\begin{tabular}{|c|c|c|}
\hline Likely to recommend & Respondents & Percentage \\
\hline Not likely at all & 6 & $7.5 \%$ \\
\hline Not likely & 16 & $20 \%$ \\
\hline Neutral & 32 & $40 \%$ \\
\hline Likely & 14 & $17.5 \%$ \\
\hline Very likely & 12 & $15 \%$ \\
\hline
\end{tabular}

(Source: Primary data)

\section{6: INTERPRETATION}

The above graph shows that $40 \%$ of the population are neutral towards likely to recommend. $20 \%$ respondents are not likely, $17.5 \%$ respondents are likely, $15 \%$ respondents are very likely, $7.5 \%$ respondents are not likely at all towards question likely to recommend.

\section{TABLE-27 INCREASE IN E-COMMERCE USING POPULATION}

\begin{tabular}{|c|c|c|}
\hline $\begin{array}{c}\text { Increase in e-commerce } \\
\text { using population }\end{array}$ & Respondents & Percentage \\
\hline Strongly disagree & 0 & $0 \%$ \\
\hline Disagree & 0 & $0 \%$ \\
\hline Neutral & 4 & $5 \%$ \\
\hline Agree & 64 & $80 \%$ \\
\hline Strongly agree & 12 & $15 \%$ \\
\hline
\end{tabular}

(Source: Primary data)

\section{7: INTERPRETATION}

The above graph shows that $80 \%$ respondents of the sample population agree that using population of e-commerce has increased over years. $15 \%$ of the respondents strongly agreed and $5 \%$ of them show neutral response for the statement that using population of e-commerce has increased over years.

\section{TABLE-28 SATISFACTION WITH PURCHASE EXPERIENCE}

\begin{tabular}{|c|c|c|}
\hline $\begin{array}{c}\text { How satisfied with } \\
\text { purchase experience }\end{array}$ & Respondents & Percentage \\
\hline Very dissatisfied & 0 & $0 \%$ \\
\hline Dissatisfied & 14 & $17.5 \%$ \\
\hline Neutral & 26 & $32.5 \%$ \\
\hline Satisfied & 24 & $30 \%$ \\
\hline Very satisfied & 16 & $20 \%$ \\
\hline
\end{tabular}

(Source: Primary data) 


\section{8: INTERPRETATION}

The above graph shows that $30 \%$ respondents are satisfied, $32.5 \%$ respondents are neutral, $20 \%$ of them are very satisfied and rest $17.5 \%$ of the respondents are dissatisfied with the purchase experience through online or e-commerce.

\section{TABLE-3.29 QUALITY OF TRADING THROUGH ONLINE}

\begin{tabular}{|c|c|c|}
$\begin{array}{c}\text { How would you rate } \\
\text { the overall quality of } \\
\text { buying and selling } \\
\text { through online }\end{array}$ & Respondents & Percentage \\
\hline Very bad & 6 & $7.5 \%$ \\
\hline Poor & 8 & $10 \%$ \\
\hline Fair & 12 & $15 \%$ \\
\hline Good & 24 & $30 \%$ \\
\hline Excellent & 30 & $37.5 \%$ \\
\hline
\end{tabular}

(Source: Primary data)

\section{9: INTERPRETATION}

The above graph shows that $37.5 \%$ respondents say that the quality of trading through online is excellent. $30 \%$ respondents say quality of trading online is good. Among remaining $15 \%$ respondents say it is fair and $10 \%$ of them say that it has poor quality. Rest $7.5 \%$ of them said it has very bad quality of trading through online.

TABLE-30 5 STAR SCALE RATING FOR E-COMMERCE

\begin{tabular}{|c|c|c|}
\hline $\begin{array}{c}\text { Five star scale rating } \\
\text { for e-commerce. }\end{array}$ & Respondents & Percentage \\
\hline Very dissatisfied & 0 & $0 \%$ \\
\hline Dissatisfied & 6 & $7.5 \%$ \\
\hline Neutral & 30 & $37.5 \%$ \\
\hline Satisfied & 44 & $55 \%$ \\
\hline Very satisfied & 0 & $0 \%$ \\
\hline
\end{tabular}

(Source: Primary data)

\section{0: INTERPRETATION}

The above chart says that $55 \%$ of respondents population are satisfied buying through e-commerce. $37.5 \%$ of respondents are showing neutral response and $7.5 \%$ respondents were dissatisfied.

\section{CONCLUSION}

Online shopping is becoming more popular day by day with the increase in usage of WORLD WIDE WEB as www. Ecommerce is continuously improving and becoming more and more pivotal to business as technology continues to advance and is something that should be taken advantage of and implemented. From the inspection of the e-commerce, the possibilities have become endless for both businesses and consumers.

From the previous data analysis project can be concluded that the awareness among people have increased as well as most of them are making use of online shopping, product information cancelling and returning of goods are clear and simple to understand and more than half of the respondents are satisfied with e-commerce.

\section{REFERENCES}

[1] Mutia Sobihah, Mahadzirah Mohamad, Nor Azman Mat Ali, Wan Zulqurnain and Wan Ismail (2015), "ECommerce Service Quality on Customer Satisfaction, Belief and Loyalty: A Proposal", Mediterranean Journal of Social Sciences MCSER Publishing, Rome-Italy, Vol 6 No 2

[2] Amit Kumar Gupta (2016), "Customer Satisfaction and Loyalty of E-commerce in India", Conference Proceeding of International Conference on "Recent Innovation in Science, Technology and Management" (ICRISTM-16) at Indian Federation of United Nations Associations (IFUNA) , New Delhi, India.

[3] Dr. A. Valarmathi (2017), "A Study on Customer Perception on Online Purchase and Digital Marketing in Coimbatore", International Journal of Latest Engineering and Management Research (IJLEMR), Volume 02 - Issue 10

[4] Mustafa I. Eid (2011), "Determinants of E-Commerce Customer Satisfaction, Trust, and Loyalty in Saudi Arabia", Article in Journal of Electronic Commerce Research.

[5] Chander Deep Purthi \& Pramod Gupta (2017), "The impact of online shopping on customer satisfaction in Indian marketing", International Journal of Marketing \& Financial Management, Volume 5, (Issue 5, May2017).

[6] Habibur Rahman , Lili Han (2011), "Customer satisfaction in E-Commerce: A case study of China and Bangladesh"

[7] Alotaibi Khalid, Ook Lee, Minkyong Choi and Jongchang Ahn (2005), "The effect of customer satisfaction with ecommerce system", Journal of Theoretical and Applied Information Technology 31st January 2018. Vol.96. No 2 (c) 2005

[8] Hluno Ezinne Chinyere \& Yakubu Joy Asmau (2017), "The Impact of e-Commerce on Customer Satisfaction: a Case Study of Kaduna State Metropolis in Nigeria", International Journal of Advanced Studies in Economics and Public Sector Management | IJASEPSM, Volume 5, Number 3 December,

[9] Ali Khatibi1, Mohd Ismail and Hishamuddin Ismail (2003), "The Effect of E- Commerce on Customer Satisfaction in Malaysia", (c) Kamla-Raj 2003, J. Soc. Sci., 7(3): 201-208 (2003)

[10] Zahra Tabaei, Mohammad Fathian and Mohammad Reza Gholamian (2011), "Effective Factors on Electronic Customers Satisfaction", International Conference on Information and Financial Engineering IACSIT Press, Singapore, vol.12

[11] Sathya (2015), "A Study on Digital Marketing and it's Impact", International Journal of Science and Research (IJSR), Volume 6 Issue 2

[12] Dr.M.Rajesh and G.Purushothaman (2013), "Consumer perception towards online shopping in Kanchipuram", International Interdisciplinary Research Journal, Vol.1 (2).

[13] Dr. K.Krishnamurthy and S.H. Rehana Banu (2015), "Customer perception and response towards online marketing in Chennai city", Asia Pacific Journal of Research Vol: I. Issue XXVII. 